\title{
Effect of ammonia concentration on rumen microbial protein production in vitro
}

\author{
Richard J. Dewhurst* and John R. Newbold \\ Dairy Research E Innovation Centre, SRUC, Barony Campus, Parkgate, Dumfries, DG1 3NE, UK \\ (Submitted 9 November 2021 - Accepted 11 November 2021 - First published online 15 November 2021)
}

Abstract

We review key findings of one the most cited papers in the 75-year history of BJN. We then identify important consequent developments, as well as opportunities to use analytical and molecular biology advances to maximise conversion of non-protein nitrogen into microbial protein.

\section{Key words: Rumen: in vitro: Ammonia: Microbial protein synthesis}

Ruminants are exquisitely adapted to convert low-grade human inedible feedstuffs into high-quality protein foods. Most notably, they convert non-protein nitrogen into high-quality protein in milk, beef and lamb as demonstrated in the classical study of Virtanen $^{(1)}$ in which dairy cows produced milk from a diet where the only $\mathrm{N}$ sources were urea and ammonium salts. Central to this ability is the synthesis of microbial protein in the rumen, much of which utilises ammonia.

'Metabolisable protein' systems for ruminants developed over the last 4 decades have attempted to incorporate estimates of protein degradation and microbial protein synthesis (MPS) in the rumen into feeding standards and rationing systems. However, both degradation and synthesis measurements are difficult to accomplish in vivo, requiring fistulated cows, and subject to large experimental errors. Before Satter and Slyter's paper, it was recognised that non-protein nitrogen is often not well utilised in diets containing high levels of non-protein nitrogen or low fermentable energy, but it was not clear at what ammonia level MPS is limited.

Satter and Slyter ${ }^{(2)}$ adopted an in vitro approach, where it is easier to control and measure inputs and outputs to understand the effects of N supply on MPS. Just as in Virtanen's work, the use of protein-free diets allowed the authors to measure MPS directly - in this case as true (tungstic acid precipitable) protein.

\section{Key findings}

Satter and Slyter's in vitro approach allowed them to conduct a series of experiments evaluating a wide range of basal diets, both synthetic (without true protein) and natural (with true protein) with graded additions of urea to evaluate the effects of rumen
$\mathrm{N}$ supply. The paper is most cited as the basis for asserting 50 $\mathrm{mg} / \mathrm{l}$ ammonia-N as the minimum level to avoid constraining MPS. Ammonia concentrations in effluent from their in vitro vessels increased above levels equivalent to 120-140 g crude protein per kg DM in the diet, whilst tungstic acid precipitable $\mathrm{N}$ plateaued at this level. Below this level, there was a major and linear decline in MPS, with more modest reductions in the production of volatile fatty acids and methane. Very high levels of ammonia-N (800 mg/l) did not impair MPS. Whilst in vitro systems are easier to control and measure, the authors recognised limitations due to the absence of absorption and $\mathrm{N}$ recycling seen in vivo.

\section{Developments since publication}

The paper accelerated to be cited over 30 times in 2000 and has been consistently cited 30-50 times in each subsequent year. The citing papers often refer to the $50 \mathrm{mg} / \mathrm{l}$ ammonia-N minima and have spanned across a range of diet types, additives and feeding strategies in many countries.

The paper was quickly challenged by in vivo work from Mehrez et al. ${ }^{(3)}$ suggesting that a much higher rumen ammonia-N concentration (194 mg/l) was needed to optimise in situ DM disappearance of barley. Those sheep were only fed mineralised rolled barley, so it seems likely that urea addition (and the resultant increased rumen ammonia) may have exerted other effects, including through rumen $\mathrm{pH}$. Our own in vitro work on rumen acidogenicity of diverse feeds ${ }^{(4)}$ illustrates the effects of degraded $\mathrm{N}$ on rumen $\mathrm{pH}$. Odle and Schafer ${ }^{(5)}$ conducted a similar study with beef cattle and showed optimal ammonia-N of $125 \mathrm{mg} / \mathrm{l}$ for degradation of barley and $61 \mathrm{mg} / \mathrm{l}$ for degradation

Abbreviations: MPS, microbial protein synthesis.

This paper was commissioned as part of the BJN's 75th Anniversary celebrations, reviewing the impact of some of the most cited papers published in the journal over that period.

* Corresponding author: Dr R. J. Dewhurst, email richard.dewhurst@sruc.ac.uk 
of maize. Indeed, earlier in vivo work mentioned by Satter and Slyter $^{(6)}$ also suggested a higher requirement, around $130 \mathrm{mg} / \mathrm{l}$, to maximise MPS. When supplementing urea to low protein fibre sources, Soliva e $_{\text {al }}{ }^{(7)}$ showed that the level at which ammonia$\mathrm{N}$ restricted in vitro fermentability of fibre varied between fibre sources (from $31 \mathrm{mg} / \mathrm{l}$ for apple pomace to $92 \mathrm{mg} / \mathrm{l}$ for Brachiaria hay). It may be that the optimum level of ammonia-N for MPS differs from that for optimal fibre digestion.

Whilst $50 \mathrm{mg} / \mathrm{l}$ ammonia-N is often cited as a minimum, some more recent in vitro work ${ }^{(8)}$ and other work from that group cited therein suggested that even lower rumen ammonia-N concentrations did not limit MPS. Over the intervening years, it has become clear that ammonia-N concentration does not tell the whole story about the effects of degradable protein on microbial growth. Rapid growth of rumen bacteria is supported by amino acids and peptides ${ }^{(9-11)}$.

Requirements for rumen $\mathrm{N}$ are usually expressed relative to rumen fermentable energy supply on a daily basis, and there was some interest in the effects of diurnal variation in the synchrony of energy and N supply on MPS, but no consistent effects from in vivo studies (reviewed by Cabrita et al. ${ }^{(12)}$ ). It is likely that the ruminant possesses mechanisms (notably the ability to recycle surplus $\mathrm{N}$ in saliva and the ability of rumen micro-organisms to accumulate storage polysaccharides during short periods of $\mathrm{N}$ deficiency) to 'buffer' short-term (within day) fluctuations in the ratio of degradable $\mathrm{N}$ : fermentable carbohydrate.

\section{Future directions}

Optimising protein feeding for ruminants is highly topical again as we need to maximise the beneficial effects of converting nonprotein nitrogen into MPS without excess rumen $\mathrm{N}$ leading to increased urinary $\mathrm{N}$ and consequent issues with nitrous oxide and ammonia losses to the air and nitrate losses to water. The fundamental observation that MPS is maximised at relatively low dietary protein levels remains useful in this quest, as are the many observations of other factors increasing MPS without increasing dietary crude protein. Prediction of MPS remains problematic, with most recent modelling accounting for only $40 \%$ of variation ${ }^{(13)}$. One approach to circumvent these challenges has been the use of proxies for MPS, including urinary purine derivatives and milk odd and branched chain fatty acids $^{(14)}$, but analytical challenges mean that these have been restricted to research settings. Whilst Satter and Slyter ${ }^{(2)}$ noted relatively normal populations of cellulolytic bacteria and entodiniomorph protozoa in their system, sequencing techniques would now allow much better analysis of the microbial community, whether in vitro or in vivo. Rumen metagenomics techniques, both at the taxa and gene levels, have been used to predict other rumen-related traits, including rumen methanogenesis and feed conversion efficiency ${ }^{(15,16)}$. We expect that this approach will support the next advances in predicting and enhancing MPS, whether by dietary or host genetic means. Lu et $a l .{ }^{(17)}$ explored the relative abundance of microbial genes involved in energy generation in relation to MPS and showed many effects of dietary energy level, but not dietary protein level; the same was true when considering microbial taxa.
The model whereby soluble proteins are deemed to be rapidly degraded in the rumen and the resultant ammonia inefficiently incorporated into microbial protein has been challenged with a suggestion that some soluble proteins may be degraded more slowly, pass from the rumen as 'undegradable soluble protein', be directly adsorbed onto bacterial cells or taken up into intracellular pools ${ }^{(18,19)}$. Whilst the next advances in enhancing rumen $\mathrm{N}$ metabolism may still use the in vitro approach of Satter and Slyter, they will be able to draw on advances in describing $\mathrm{N}$ fractions in feed and digesta, as well as microbial taxa and genes.

\section{Acknowledgements}

SRUC received funding from the Scottish Government's Strategic Research Programme.

RJD and JRN both contributed to the writing and editing of the manuscript and approved the final version.

There are no conflicts of interest.

\section{References}

1. Virtanen AI (1966) Milk production of cows on protein-free feed. Science 153, 1603-1614.

2. Satter LD \& Slyter LL (1974) Effect of ammonia concentration on rumen microbial protein production in vitro. BrJ Nutr 32, 199208.

3. Mehrez AZ, Ørskov ER \& McDonald I (1977) Rates of rumen fermentation in relation to ammonia concentration. Br J Nutr 38, 437-443.

4. Wadhwa D, Beck NFG, Borgida LP, et al. (2001) Development of a simple in vitro assay for estimating net rumen acid load from diet ingredients. J Dairy Sci 84, 1109-1117.

5. Odle J \& Schaefer DM (1987) Influence of rumen ammonia concentration on the rumen degradation rates of barley and maize. Br J Nutr 51, 127-138.

6. Hume ID, Moir RJ \& Somers M (1970) Synthesis of microbial protein in the rumen. 1. Influence of the level of nitrogen intake. Austr J Agric Res 21, 283-296.

7. Soliva CR, Amelchanka SL \& Kreuzer M (2015) The requirements for rumen-degradable protein per unit of fermentable organic matter differ between fibrous feed sources. Front Microbiol 6, 715 .

8. Sari M, Ferret A \& Calsamiglia S (2015) Effect of $\mathrm{pH}$ on in vitro microbial fermentation and nutrient flow in diets containing barley straw or non-forage fiber sources. Anim Feed Sci Technol 200, 17-24.

9. Cotta MA \& Russell JB (1982) Effect of peptides and amino acids on efficiency of rumen bacterial protein synthesis in continuous culture. J Dairy Sci 65, 226-234.

10. Carro MD \& Miller EL (1999) Effect of supplementing a fibre basal diet with different nitrogen forms on ruminal fermentation and microbial growth in an in vitro semi-continuous culture system (RUSITEC). Br J Nutr 82, 149-157.

11. Calsamiglia S, Ferret A, Reynolds CK, et al. (2010) Strategies for optimizing nitrogen use by ruminants. Animal 4, 1184-1196.

12. Cabrita ARJ, Dewhurst RJ, Abreu JMF, et al. (2006) Critical evaluation of the effects of synchronising the availability of $\mathrm{N}$ and energy in the rumen. Anim Res 55, 1-24.

13. Galyean M \& Tedeschi LO (2014) Predicting microbial protein synthesis in beef cattle: relationship to intakes of total digestible nutrients and crude protein. J Anim Sci 92, 5099-5111. 
14. Dewhurst RJ, Davies DR \& Merry RJ (2000) Microbial protein supply from the rumen. Anim Feed Sci Technol 85, 1-21.

15. Lima J, Auffret MD, Stewart RD, et al. (2019) Identification of rumen microbial genes involved in pathways linked to appetite, growth, and feed conversion efficiency in cattle. Front Genet 10, 701.

16. Martinez-Alvarez M, Auffret MD, Stewart RD, et al. (2020) Identification of complex rumen microbiome interaction within diverse functional niches as mechanisms affecting the variation of methane emissions in bovine. Front Microbiol 11, 659.
17. Lu Z, Xu Z, Shen Z, et al. (2019) Dietary energy level promotes rumen microbial protein synthesis by improving the energy productivity of the ruminal microbiome. Front Microbiol $\mathbf{1 0}$, 847.

18. Hedqvist H \& Udén P (2006) Measurement of soluble protein degradation in the rumen. Anim Feed Sci Technol 126, $1-21$.

19. Stefański T, Ahvenjärvi S, Vanhatalo A, et al. (2020) Ruminal metabolism of ammonia $\mathrm{N}$ and rapeseed meal soluble $\mathrm{N}$ fraction. J Dairy Sci 103, 7081-7093. 